\title{
Perbandingan Faktor Risiko Pasien Limfadenitis Tuberkulosis antara Hasil Bakteri Tahan Asam Positif dan Negatif
}

\author{
Naufal Fadhillah Alam, ${ }^{1}$ Meta Maulida D, ${ }^{2}$ Maya Tejasari, ${ }^{3}$ Ismet M Nur, ${ }^{2}$ Yani Triyani4 \\ ${ }^{1}$ Program Studi Pendidikan Dokter, ${ }^{2}$ Departemen Patologi Anatomi, ${ }^{3}$ Departemen Histologi, \\ ${ }^{4}$ Departemen Patologi Klinik, Fakultas Kedokteran Universitas Islam Bandung
}

\begin{abstract}
Abstrak
Limfadenitis tuberkulosis merupakan tuberkulosis ekstraparu (TEBP) yang paling umum di dunia. Diagnosis pasti TEBP ditegakkan dengan pemeriksaan klinis, bakteriologis, dan atau histopatologis contoh uji yang diambil dari organ tubuh yang terkena. Pemeriksaan BTA dengan Ziehl Neelsen langsung pada jaringan mempunyai sensitivitas rendah sehingga jarang dilakukan. Penelitian ini bertujuan menganalisis perbandingan faktor risiko limfadenitis tuberkulosis dengan hasil BTA positif dan negatif dari jaringan KGB berdasar atas usia, jenis kelamin, dan riwayat TB paru di Laboratorium Rumah Sakit Al-Islam Bandung tahun 2016-2017. Terdapat 18 pasien dengan hasil BTA positif dan 17 pasien dengan BTA negatif yang memenuhi kriteria inklusi. Penelitian ini menggunakan desain penelitian potong lintang dengan analisis data univariat untuk mengetahui gambaran faktor risiko pasien dan bivariat untuk melihat hasil perbandingan faktor risiko pasien. Hasil penelitian ini menunjukkan pasien dengan BTA positif banyak diderita oleh pasien usia <20 tahun (8 dari 18) dan BTA negatif 30-39 tahun (6 dari 17). Pasien wanita mendominasi BTA positif (15 dari 18) dan BTA negatif (11 dari 17) daripada laki-laki. Pasien yang tidak mempunyai riwayat TB paru mendominasi BTA positif (14 dari 18) dan BTA negatif (14 dari 17). Perbandingan faktor risiko pasien antara hasil BTA positif dan negatif berdasar atas usia $(p=0,117)$, jenis kelamin $(p=0,264)$, dan riwayat TB paru $(\mathrm{p}=1,000)$. Walaupun mempunyai sensitivitas yang rendah, pemeriksaan BTA jaringan harus dilakukan guna memberikan informasi yang maksimal untuk klinisi. Simpulan, perbandingan faktor risiko limfadenitis tuberkulosis antara hasil BTA positif tidak berbeda.
\end{abstract}

Kata kunci: Faktor risiko, limfedenitis tuberkulosis, tuberkulosis ekstraparu

\section{Comparasion of Lymphadenitis Tuberculosis Patient's Risk Factor between Positive and Negative Acid-Fast Bacillus}

\begin{abstract}
Lymphadenitis tuberculosis is most common extrapulmonary tuberculosis (EPTB) in the world. Definitive diagnosis in EPTB is by clinical examination, bacterial examination, and histopatological examination from sample in affected organ. AFB examination by Ziehl Neelsen directly from tissue has low sensitivity and high specificity. This study aims to examine the comparion of lymphadenitis tuberculosis patient's risk factor between positive and negative AFB from lymph node tissue based on age, sex, and previous history of pulmonary tuberculosis in Laboratory of AlIslam Hospital Bandung during 2016-2017. There were 18 patients with positive AFB and 17 patients with negative AFB who met inclusion criteria. This study used cross sectional design with univariate data analysis to descript the risk factor of patients and bivariate to see the comparison of patient characteristics. The result of this study showed patient with positive AFB occur more at the age of $<20$ ( 8 of 18) and negative AFB occur more at the age of 30-39 ( 6 of 17). Woman were dominated positive AFB (15 of 18) and negative AFB (11 of 17) than man. Patients with no previous pulmonary tuberculosis history were dominated positive AFB (14 of 18) and negative AFB (14 of 17). Comparison of lymphadenitis tuberculosis patient's risk factor between positive and negative AFB based on age $(\mathrm{p}=0.117)$, sex $(\mathrm{p}=0.264)$, and previous history of pulmonary tuberculosis $(\mathrm{p}=1.000)$. Despite low sensitivity, tissue AFB examination should be performed to give maximal information for clinician. Conclusion, comparison of lymphadenitis tuberculosis risk factor between positive and negative AFB is not different.
\end{abstract}

Keywords: Extrapulmonary tuberculosis, lymphadenitis tuberculosis, risk factor 


\section{Pendahuluan}

Tuberkulosis (TB) merupakan penyakit infeksi yang disebabkan oleh basil Mycobacterium tuberculosis yang biasanya mengenai paru (TB paru), tetapi juga dapat mengenai organ-organ lain (TB ekstraparu). Penyakit ini menyebar ketika seseorang yang terkena TB paru mengeluarkan bakteri ke udara contohnya ketika batuk. ${ }^{1}$ Tuberkulosis ekstraparu (TBEP) dapat terjadi pada semua bagian tubuh seperti kelenjar getah bening (KGB), pleura, abdomen, kulit, tulang, sendi, saluran kencing, dan sebagainya. Limfadenitis TB merupakan TBEP yang paling umum di dunia sebanyak $30-40 \% .^{2-4}$ Penyakit tuberkulosis merupakan penyakit infeksi menular dengan angka kejadian tertinggi di dunia, diperkirakan terdapat 6,3 juta kasus baru TB pada tahun 2016 di dunia. Tuberkulosis ekstraparu berjumlah $15 \%$ dari 6,3 juta kasus pada tahun $2016 .{ }^{1}$

Berdasar atas Pedoman Nasional Pengendalian Tuberkulosis Tahun 2016, diagnosis pasti pada pasien tuberkulosis ekstraparu dapat ditegakkan bersama atas pemeriksaan klinis, pemeriksaan bakteriologis, dan atau histopatologis dari contoh uji yang diambil dari organ tubuh yang terkena. ${ }^{4}$

Diagnosis tuberkulosis ekstraparu menggunakan pemeriksaan BTA dengan Ziehl Neelsen langsung pada jaringan mempunyai sensitivitas yang rendah dan spesifisitas yang tinggi, sedangkan pemeriksaan histopatologi pada jaringan mempunyai sensitivitas yang tinggi dan spesifisitas yang rendah. Pemeriksaan BTA dari biopsi jaringan sudah jarang dilakukan karena sensitivitas untuk diagnosis, namun akan lebih baik untuk menggunakan semua pemeriksaan yang ada yang akan menyediakan informasi berguna yang maksimal untuk klinisi. ${ }^{5}$

Penelitian Nassaji dkk. ${ }^{2}$ di Iran pada tahun 2014 melaporkan hasil positif BTA pada biopsi jaringan tuberkulosis dan hubungannya dengan faktor risiko pasien didapatkan laki-laki $23,8 \%$ dan perempuan $28,1 \%$, usia paling banyak pada $>70$ tahun $47,3 \%$, pasien dengan riwayat TB paru positif $50 \%$, dan riwayat TB paru negatif $5,7 \%$, pasien yang terdapat penyakit komorbid 50\% dan pasien yang tidak terdapat penyakit komorbid 5,7\%. ${ }^{2}$ Penelitian García-Rodríguez dkk. ${ }^{3}$ melaporkan kejadian TBEP meningkat seiring dengan pertambahan usia dan jenis kelamin wanita. Menurut penelitian lain yang dilakukan oleh Azizi dkk. ${ }^{6}$ di Balai Besar Kesehatan Paru Masyarakat (BBKPM) Bandung pada tahun 2014 penderita TBEP terbanyak pada rentang usia 20-50 tahun dan lokasi terbanyak adalah di daerah KGB yang disebut dengan limfadenitis TB.

Rumah Sakit Al Islam merupakan rumah sakit jejaring Fakultas Kedokteran Universitas Islam Bandung yang telah melakukan beberapa penelitian mengenai TBEP dengan melihat hasil BTA dari bahan pemeriksaan biopsi jaringan yang diperiksa dengan Metode Ziehl Neelsen. Laporan kasus pada bulan Desember 2015 sampai dengan Juli 2016 didapatkan 31 pasien dengan hasil BTA positif dari biopsi jaringan. Belum dilakukan penelitian mengenai perbandingan faktor risiko pasien limfadenitis TB antara hasil BTA positif dan BTA negatif dari jaringan KGB di Rumah Sakit Al Islam Bandung.

Tujuan penelitian ini adalah meneliti perbandingan faktor risiko pasien limfadenitis TB antara hasil BTA positif dan negatif dari jaringan KGB di Rumah Sakit Al Islam Bandung berdasar atas usia, jenis kelamin, dan riwayat TB paru tahun 2016-2017.

\section{Metode}

Subjek penelitian yang dipergunakan adalah data sekunder berupa rekam medik pasien limfadenitis TB berdasar atas pemeriksaan histopatologi di Laboratorium Rumah Sakit Al Islam tahun 2016-2017. Sampel penelitian ini diambil menggunakan total sampling, yaitu mengambil seluruh subjek penelitian yang termasuk dalam kriteria inklusi. Kriteria inklusi penelitian ini adalah rekam medik pasien yang sudah memiliki data diagnosis limfadenitis tuberkulosis berdasar atas pemeriksaan histopatologi yang memiliki data usia, jenis kelamin, dan riwayat TB paru. Besar sampel minimal ditentukan berdasar atas estimasi proporsi 2 kelompok independen untuk data kategorik berjumlah sekurang-kurangnya 30 orang.

Penelitian didahului dengan pembuatan preparat dari blok parafin jaringan KGB pasien, kemudian dilakukan pewarnaan BTA Ziehl Neelsen. Preparat tersebut kemudian dibaca berdasar atas ada tidak BTA menggunakan mikroskop pembesaran 1.000x. Hasilnya dikategorikan positif bila ditemukan BTA dalam 100 lapang pandang dan negatif bila tidak ditemukan BTA dalam 100 lapang pandang. Sampel penelitian ini berjumlah 35 orang yang terdiri atas 18 pasien dengan hasil BTA positif dan 17 pasien dengan hasil BTA negatif dari jaringan KGB.

Analisis data didahului dengan melakukan analisis univariat untuk mengetahui faktor risiko pasien limfadenitis TB dengan hasil BTA positif dan negatif dari jaringan KGB ditinjau berdasar atas atas usia, jenis kelamin, dan riwayat TB paru. Selanjutnya, dilakukan analisis bivariat secara analitik komparatif untuk data kategorik menggunakan statistik Fisher exact untuk membandingkan faktor risiko pasien antara hasil BTA positif dan negatif berdasar atas usia, jenis kelamin, dan riwayat TB. Analisis data menggunakan derajat kerpercayaan $95 \%$ dengan nilai $\mathrm{p} \leq 0,05$. Penelitian ini sudah mendapat persetujuan etik oleh Komite Etik Penelitian Kesehatan Fakultas Kedokteran Universitas Islam Bandung dengan Nomor: 294/Komite Etik.FK/ III/2018.

\section{Hasil}

Penelitian dilakukan terhadap 35 pasien limfadenitis TB yang terdiri atas 17 pasien BTA negatif dan 18 pasien BTA positif. Nilai p dihitung berdasar atas Uji Eksak Fisher dengan derajat kepercayaan 95\%. Nilai kemaknaan berdasar atas nilai $\mathrm{p}<0,05$.

Pasien limfadenitis TB dengan hasil BTA jaringan KGB positif terbanyak pada kelompok usia $<20$ tahun, sedangkan hasil BTA negatif adalah usia 30-39 tahun. Limfadenitis TB baik dengan hasil BTA positif dan negatif didominasi oleh perempuan (BTA positif 15 dari 18 dan BTA negatif 11 dari 17). 


\begin{tabular}{|c|c|c|c|c|}
\hline \multirow[t]{3}{*}{ Tabel } & \multicolumn{4}{|c|}{$\begin{array}{l}\text { Perbandingan Faktor Risiko Pasie } \\
\text { Limfadenitis TB dengan Hasil BT } \\
\text { Positif dan Negatif }\end{array}$} \\
\hline & \multirow[b]{2}{*}{ ktor Risiko } & \multicolumn{2}{|c|}{ BTA } & \multirow[b]{2}{*}{$\mathbf{p}$} \\
\hline & & $\begin{array}{c}\text { Negatif } \\
\mathbf{n}=\mathbf{1} 7\end{array}$ & $\begin{array}{c}\begin{array}{c}\text { Positif } \\
n=18\end{array} \\
\text { not }\end{array}$ & \\
\hline \multicolumn{4}{|c|}{ Usia (tahun) } & \multirow{8}{*}{0,117} \\
\hline$<2$ & & 1 & 8 & \\
\hline 20 & & 4 & 3 & \\
\hline $30-$ & & 6 & 3 & \\
\hline $40-$ & & 2 & 2 & \\
\hline $50-$ & & 3 & 2 & \\
\hline $60-$ & & 1 & o & \\
\hline$\geq 7$ & & o & o & \\
\hline \multicolumn{4}{|c|}{ Jenis kelamin } & \multirow{3}{*}{0,264} \\
\hline Lak & laki & 6 & 3 & \\
\hline Per & npuan & 11 & 15 & \\
\hline \multicolumn{4}{|c|}{ Riwayat TB paru } & \multirow{3}{*}{1,000} \\
\hline Tid & ada & 14 & 14 & \\
\hline Ada & & 3 & 4 & \\
\hline
\end{tabular}

Pasien limfadenitis TB baik dengan hasil BTA positif maupun BTA negatif dari jaringan KGB mayoritas tidak memiliki riwayat TB paru sebelumnya. Analisis bivariat tidak terdapat perbedaan bermakna antara BTA positif dan negatif berdasar atas usia $(p=0,117)$, jenis kelamin $(p=0,264)$, dan riwayat TB paru $(\mathrm{p}=1,000)$. (Tabel)

\section{Pembahasan}

Pada tahun 2016-2017 terdapat 35 kasus limfadenitis TB yang dilakukan biopsi di Laboratorium Rumah Sakit Al Islam Bandung. Pasien limfadenitis TB dengan hasil BTA negatif dari jaringan KGB banyak diderita oleh pasien dengan rentang usia 30-39 tahun sementara pasien dengan hasil BTA positif banyak diderita oleh pasien dengan rentang usia $<20$ tahun. Hal tersebut tidak sejalan dengan penelitian yang dilakukan oleh Nassaji dkk. ${ }^{2}$ di Iran tahun 2014 yang menyatakan bahwa hasil BTA positif cenderung didapatkan pada pasien usia $>70$ tahun. Penelitian Eshete dkk. ${ }^{7}$ menyatakan dari total hasil BTA positif 30 (81\%) pasien berada pada usia $15-45$ tahun, 7 $(18,9 \%)$ berada pada usia di bawah 15 tahun dan tidak ada pasien dengan BTA positif pada usia $>45$ tahun.

Pembentukan granuloma adalah salah satu respons imun tubuh untuk mencegah penyebaran bakteri $M$. tuberculosis lebih lanjut sehingga pada pemeriksaan BTA dari jaringan biopsi menunjukkan sensitivitas yang sangat rendah. Selain itu, ditambah distribusi bakteri di dalam jaringan tidak merata karena sulit untuk melakukan homogenisasi pada spesimen

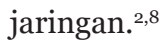

Pada penelitian Nassaji dkk. ${ }^{2}$ hasil BTA positif cenderung didapatkan pada pasien usia >70 tahun, hal tersebut dapat diakibatkan oleh sistem imun yang mulai menurun sehingga respons imun pembentukan granuloma tidak sempurna sehingga pada pemeriksaan BTA jaringan lebih cenderung untuk ditemukan bakteri. Di samping itu, distribusi usia kependudukan di iran dan di Indonesia tidak sama. ${ }^{2,9,10}$

Pasien hasil BTA negatif pada penelitian ini lebih banyak terjadi pada rentang usia 30-39 tahun, kemudian diikuti oleh 20-29 tahun atau dapat disimpulkan pada kelompok ini lebih sering terjadi pada pasien usia produktif. Hal ini sejalan dengan penelitian yang dilakukan oleh Eshete dkk., Nidhi dkk. ${ }^{11}$ dan Popescu dkk. ${ }^{9}$ yang menyatakan limfadenitis TB sering terjadi pada usia produktif pada dekade 2 sampai dengan 4 kehidupan. Usia produktif memengaruhi risiko tinggi untuk terkena TB karena mobilitas yang tinggi pada usia produktif sehingga kecenderungan berinteraksi dengan orang banyak di wilayah kerja lebih tinggi dibanding dengan bukan usia produktif sehingga insidensi TB banyak mengenai usia produktif. Pada penelitian ini pasien dengan rentang usia produktif tersebut lebih banyak memiliki hasil BTA negatif, hal tersebut dapat disebabkan oleh salah satunya faktor respons imunitas pasien yang lebih baik sehingga pembentukan granuloma sebagai respons imunitas pasien dalam meminimalisir penyebaran bakteri bekerja lebih baik yang menyebabkan saat dilakukan pewarnaan hanya sedikit atau bahkan sudah tidak ada lagi BTA yang dapat ditemukan.

Pasien limfadenitis TB baik yang mempunyai hasil BTA negatif dan positif dari jaringan KGB lebih banyak terjadi pada perempuan dibanding dengan laki-laki serta pada pasien yang tidak memiliki riwayat TB paru. Penelitian berdasar atas jenis kelamin pada penelitian ini sama dengan penelitian sebelumnya yang dilakukan oleh Salvador dkk., ${ }^{12}$ Eshete dkk., ${ }^{7}$ Nidhi dkk., ${ }^{11}$ Popescu dkk., ${ }^{9}$ dan Garcia-Rodríguez dkk. ${ }^{3}$ yang menyatakan perempuan lebih banyak terkena dibanding dengan laki-laki dengan rasio $>2: 1$. Alasan peningkatan risiko yang lebih tinggi pada perempuan belum dimengerti dengan baik dan faktor penjamu yang mungkin memengaruhi dapat mencakup kegiatan okupasional dan sosial serta mendukung pajanan orofaring terhadap mycobacteria, pengaruh genetik dan hormonal, atau perbedaan dalam health-seeking behavior. Pada penelitian ini, proporsi perempuan lebih banyak dapat disebabkan oleh distribusi data perempuan lebih banyak dibanding dengan laki-laki juga kebiasaan merokok pada perempuan semakin meningkat sehingga kerentanan terhadap TBEP salah satunya limfadenitis TB pada perempuan menjadi meningkat. Hasil penelitian ini juga sama dengan penelitian sebelumnya yang dilakukan oleh Nassaji dkk. ${ }^{2}$ yang menyatakan proporsi jenis kelamin dengan hasil BTA positif lebih banyak pada perempuan. ${ }^{2}$

Penelitian berdasar atas riwayat TB paru pada penelitian ini berbeda dengan penelitian sebelumnya yang dilakukan oleh Nassaji dkk. ${ }^{2}$ yang menyatakan bahwa hasil BTA positif sebagian besar didapatkan pada pasien yang miliki riwayat TB paru. Hal ini berhubungan dengan status imunitas pasien saat mengalami episode TB kedua. Faktor menyebabkan terjadi rekurensi dari riwayat $\mathrm{TB}$ sebelumnya dapat dipengaruhi oleh faktor pengobatan yang tidak adekuat, imunitas, dan kuman TB. Penelitian Sreeramareddy dkk. ${ }^{13}$ menunjukkan bahwa hanya 10 (4,3\%) pasien TBEP yang mempunyai riwayat TB paru sebelumnya. Hasil yang sama juga dinyatakan pada 
penelitian Rahman dkk. ${ }^{14}$ bahwa hanya $18,8 \%$ pasien yang mempunyai riwayat TB paru sebelumnya.

\section{Simpulan}

Tidak terdapat perbedaan faktor risiko limfadenitis tuberkulosis berdasar atas usia, jenis kelamin, dan riwayat TB paru antara hasil BTA positif dan BTA negatif.

\section{Ucapan Terima Kasih}

Ucapan terima kasih kepada pimpinan RS Al-Islam Bandung sebagai tempat pelaksanaan penelitian ini.

\section{Daftar Pustaka}

1. WHO. Global tuberculosis report 2017. [diunduh 12 April 2019]. Tersedia dari: http://apps.who. int/iris/bitstream/10665/259366/1/9789241565 516eng.pdf?ua $=1$

2. Nassaji M, Azarhoush R, Ghorbani R, Kavian F. Acid fast straining in formalin fixed tissue specimen of patients with extrapulmonary tuberculosis. Int J Sci Res Publ. 2014;4(10):4-8.

3. García-Rodríguez JF, Álvarez-Díaz H, LorenzoGarcía MV, Mariño-Callejo A, Fernández-Rial Á, Sesma-Sánchez P. Extrapulmonary tuberculosis: epidemiology and risk factors. Enferm Infecc Microbiol Clin. 2011 Aug 1;29(7):502-9.

4. Subuh M, Priohutomo S, Widaningrup C, Dinihari TN, Siaglan V. Pedoman Nasional Pengendalian Tuberkulosis. Jakarta: Kementrian Nasional; 2014.

5. Purohit M, Mustafa T. Laboratory diagnosis of extra-pulmonary tuberculosis (EPTB) in resource-constrained setting: state of the art, challenges and the need. J Clin Diagn Res. 2015;9(4):1-6.
6. Azizi FH, Husin UA, Rusmantini T. Gambaran karakteristik tuberkulosis paru dan ekstraparu di BBKPM Bandung tahun 2014. Prosiding Pendidikan Dokter. 2014;860-6.

7. Eshete A, Zeyinudin A, Ali S, Abera S, Mohammed M. M. tuberculosis in lymph node biopsy paraffin-embedded sections. Tuberc Res Treat. 2011;2011(127817):1-5.

8. Miller K, Harrington SM, Procop GW. Acidfast smear and histopathology results provide guidance for the appropriate use of broad-range polymerase chain reaction and sequencing for mycobacteria. Arch Pathol Lab Med. 2015;139(8):1020-3.

9. Popescu MR, Calin G, Strambu I, Olaru M, Balasoiu M, Huplea V, dkk. Lymph node tuberculosis an attempt of clinico- morphological study and review of the literature. Rom J Morphol Embryol. 2014;55(2):553-67.

10. Ennouri A, Zermani R, Mezni M, Marrekchi H, Atallah M. Lymph node tuberculosis. Rev Laryngol Otol Rhinol. 2016;110(2):179-81.

11. Nidhi P, Sapna T, Shalini M, Kumud G. FNAC in tuberculous lymphadenitis: experience from a tertiary level referral centre. Indian $\mathrm{J}$ Tuberc. 2011;58(3):102-7.

12. Salvador F, Los-Arcos I, Sánchez-Montalvá A, Tórtola T, Curran A, Villar A, dkk. Epidemiology and diagnosis of tuberculous lymphadenitis in a tuberculosis low-burden country. Medicine (Baltimore). 2015;94(4):3-8.

13. Sreeramareddy CT, Panduru KV, Verma SC, Joshi HS, Bates MN. Comparison of pulmonary and extrapulmonary tuberculosis in Nepal-a hospital-based retrospective study. BMC Infect Dis. 2010;8:1-7.

14. Rahman S, Quddus R, Arif S. A clinical study on extra-pulmonary tuberculosis. J Bangladesh Coll Physicians Surg. 2010;24(1):10-28. 